\title{
MODEL KOMUNIKASI PERKAWINAN JARAK JAUH
}

\author{
Arina Rubyasih* \\ Universitas Terbuka
}

\begin{abstract}
ABSTRAK
Komunikasi pasangan suami istri jarak jauh pada penelitian ini dilatar belakangi oleh keunikan pasangan suami istri yang seharusnya hidup dalam satu tempat tinggal yang sama tetapi harus terpisah ruang dan waktu. Selain itu tidak semua pasangan suami istri mampu menjalani pernikahan jarak jauh dan bisa mempertahankan pernikahannya sampai saat ini. Tujuan penelitian ini adalah untuk (1) mengetahui latar belakang pasangan suami istri berkomunikasi jarak jauh; (2) mengetahui makna keharmonisan bagi pasangan suami istri yang melakukan komunikasi jarak jauh; (3) mengetahui pengalaman komunikasi bermedia pada pasangan suami istri jarak jauh. Metode yang digunakan dalam penelitian ini adalah metode kualitatif dengan pendekatan studi kasus. didapatkan dari enam pasangan suami istri yang melakukan komunikasi jarak jauh dengan menggunakan teknik pengamatan non partisipan dan wawancara mendalam. Hasil penelitian ini menunjukkan bahwa (1) latar belakang melakukan komunikasi pasangan suami istri jarak jauh tediri dari beberapa aspek: a. Jodoh, b. Tugas belajar, c. Penempatan tugas kerja, d. Tuntutan ekonomi; (2) Makna keharmonisan terdiri dari beberapa aspek: a. Saling percaya, b. Keterbukaan, c. Pengertian, d. Perhatian, e. Berpikir positif, f. Saling komunikasi, g. Menghargai, h. Memecahkan masalah; (3) Pengalaman komunikasi bermedia pasangan suami istri jarak jauh, pengalaman komunikasi dibagi menjadi tiga bagian yaitu a. Komunikasi bermedia, b. Rutinitas komunikasi (pagi, siang, malam), c. Kendala komunikasi (sinyal, biaya, dan waktu).
\end{abstract}

Kata-kata kunci: Komunikasi, jarak jauh, pasangan suami istri, penggunaan media, studi kasus

\section{LONG DISTANCE COMMUNICATION MODEL OF MARRIED COUPLE}

\section{ABSTRACT}

The background of the study is the uniqueness of the marriage couple who should live in the same residence, must be separated. Moreover, not all of the couple are able to live in a long distance marriage and maintain the marriage until now. The purposes of the study are (1) To find out the background of long distance communication between married couple; (2) To find out the meaning of harmony of married couple in long distance communication; (3) to find out the experience in communication by using the media of the marriage couple in long distance. The study uses qualitative methodology by using case study. The source of the study is six married couple who do long distance communication. The study uses non-participant observation technique and depth interviews. The results are: (1) The backgrounds of long distance communication between married couple are; (a) mate; (b) because of academic interest; (c) because of the placement of work; (d) economic demands. (2) The meaning of harmony for them (a) the trust between couple; (b) the openness between them, (c)openness; (d) attention; (e) think positive; (f) communication; ( $g$ ) appreciate; (h) solve problem. (3) The experience in communication by using the media is divided into three parts. (a) mediated communication; (b) communication routines (morning, afternoon, evening); (c) the communication's constraint (the signal, cost and the time).

Keywords: Communication, long distance, married couple, media use, case study

\footnotetext{
* Korespondensi: Arina Rubyasih, S.Sos., M.I.Kom. Unit Program Belajar Jarak Jauh - Universitas Terbuka. Jalan K.H Soleh Iskandar No. 234 Tanah Sareal Bogor 16164 .Email: arinar@ecampus.ut.ac.id
} 


\section{PENDAHULUAN}

Hakikat perkawinan adalah menyatukan dua manusia yaitu laki-laki dan perempuan dalam satu ikatan legal untuk membina rumah tangga. Perkawinan merupakan komitmen yang didalamnya terdapat ikatan emosional antara dua orang untuk saling berbagi antara tanggung jawab psikis maupun biologis. Perkawinan yang terjadi dilandasi rasa cinta dan kasih sayang yang dijalani secara bersama dan berdampingan antara pasangan suami istri. Perkawinan diresmikan melalui suatu peristiwa pernikahan, pasangan suami istri yang telah resmi menikah idealnya memilih untuk hidup bersama dalam satu atap, daerah yang sama, dan menghabiskan waktu secara bersama. Namun, seiring perkembangan dan kebutuhan ekonomi yang semakin meningkat banyak pasangan suami istri yang tinggal berjauhan. Karena tuntutan dari pekerjaan yang mereka geluti, pernikahan yang dijalani oleh pasangan suami istri di sini adalah pernikahan jarak jauh.

Pernikahan jarak jauh dijelaskan oleh Maines (1993) bahwa pernikahan jarak jauh adalah pernikahan terpisah antara suami dengan istri yang didasari atas komitmen sebelum pernikahan karena tuntutan karir atau pekerjaan (Margiani \& Ekayati, 2013: 192). Berdasarkan pengertian tersebut, pernikahan jarak jauh dilakukan pasangan suami istri semata-mata karena tuntutan pekerjaan dimana pasangan tersebut telah memiliki komitmen dan dapat menerima konsekuensi yang akan berimbas kepada keharmonisan rumah tangga. Seperti pernikahan jarak jauh yang dibahas dalam penelitian ini khususnya terjadi di dalam lingkungan universitas yang lingkupnya nasional yakni Universitas Terbuka (UT). Universitas Terbuka memiliki Unit Program Belajar Jarak Jauh (UPBJJ) yang berada di setiap ibukota provinsi yang memiliki peran untuk memudahkan mahasiswa di daerah-daerah di tiap kabupaten provinsi yang berkeinginan untuk mengenyam perkuliahan. UT dengan 39 UPBJJ yang mewakili tiap provinsi membutuhkan kerja sama antara dosen, mahasiswa, dan staf administrasi dalam prosesnya, sehingga perkuliahan yang berlangsung bisa berjalan dengan lancar.

Berangkat dari fenomena yang ter-jadi secara internal di dalam lingkup UT khusus- nya di tiap-tiap UPBJJ, dosen maupun staf administrasi banyak yang menjalani pernikahan jarak jauh. UT merupakan lembaga yang mengakomodir pendidikan jarak jauh yang bertujuan untuk pemerataan pendidikan hingga ke pelosok Indonesia. Dosen dan staf administrasi yang bekerja di lingkungan UT siap ditugaskan ke daerah yang terdapat UPBJJ. Kondisi ini menyebabkan dosen dan staf administrasi tersebut berpisah dengan keluarga baik dalam waktu sebentar atau selamanya. Selain tugas pekerjaan di lingkungan UT terdapat beberapa dosen yang harus terpisah dengan pasangannya untuk sementara waktu karena mereka mendapat kesempatan tugas belajar guna meningkatkan kredibilitas dalam mengajar.

Berdasarkan data jumlah dosen dan staf administrasi UT di Indonesia hingga tahun 2014 terdapat 1724 orang dengan kategori dosen berjumlah 723 orang dan staf administrasi berjumlah 1001 orang (Universitas Terbuka, 2014). Sebagian besar dosen dan staf administrasi UT dari berbagai UPBJJ yang menjalani pernikahan jarak jauh dikarenakan adanya tugas pokok dan fungsi (tupoksi) penempatan tugas bekerja, dan tugas belajar. Dua hal ini menjadi alasan yang dialami oleh beberapa dosen dan staf administrasi UT dalam melakukan komunikasi keluarga jarak jauh. Peneliti memilih 5 UPBJJ yang ada di UT yakni UPBJJ Ternate, Padang, Palu, Pangkal Pinang dan Bandung.

Selain faktor penempatan kerja, beberapa pasangan suami istri yang menjalani hubungan jarak jauh dikarenakan salah satu pasangan mendapat tugas belajar di luar kota. Salah satunya dialami oleh ND yang berasal dari UPBJJ Palu yang mendapatkan kesempatan tugas belajar untuk melanjutkan pendidikannya di Institut Pertanian Bogor (IPB). Jodoh, pemindahan kerja, penempatan, dan tugas belajar ke luar kota atau pulau menjadi alasan terjadinya pernikahansuami istri jarak jauh. Terdapat berbagai alasan yang melandasi terjadinya pernikahan jarak jauh diantaranya pekerjaan, pendidikan, adaptasi karena kesukaran menyesuaikan diri di tempat pasangannya, kebutuhan khusus, kesehatan dan keamanan. Faktor ekonomi menyebabkan pasangan suami istri harus merelakan hidup terpisah demi terpenuhinya kebutuhan hidup 
sehari-hari. Faktor lain yang memungkinkan terpisahnya suami dan istri untuk sementara waktu karena salah satu dari mereka mendapatkan pekerjaan atau tugas kerja ke luar kota dalam waktu yang lama. Di sisi lain, faktor pendidikan juga memungkinkan suami istri untuk berpisah sementara waktu karena semakin tinggi pendidikan akan semakin jauh mengakses pendidikan tersebut.

Bagisuamiistriyangmenjalanipernikahan jarak jauh dibutuhkan komitmen yang tinggi untuk membangun dan mempertahankan rumah tangga mereka. Hubungan yang dilakukan secara jauh menjadi suatu tantangan yang cukup berat. Hal ini disebabkan kondisi yang penuh dengan permasalahan tersendiri, terdapat beragam kendala yang akan dihadapi diantaranya tidak dapat berkomunikasi secara langsung serta tatap muka dengan pasangan, tidak terpenuhinya kebutuhan batiniah, tidak merasa lengkap karena tidak ada salah satu diantaranya, tidak dapat mengambil keputusan secara cepat, kurangnya perhatian dari pasangan.

Komunikasi diantara pasangan mempunyai peranan penting agar tidak memiliki dampak negatif sehingga mengganggu keharmonisan pasangan. Komunikasi sering dilakukan untuk menjaga kesinambungan dalam berhubungan dengan pasangan. Hal ini juga dilakukan oleh dosen UT yang melakukan hubungan jarak jauh dengan pasangannya. yang senantiasa menjaga komunikasi melalui berbagai cara. Perasaan cemas juga ada di saat salah satu pasangan ketika tidak memberikan kabar dalam waktu tertentu. Ada banyak penyebab tidak mengabari pasangan, diantaranya jam bekerja yang padat, gangguan teknologi seperti ketersediaan sinyal dan fasilitas lainnya. Jam bekerja yang sibuk terkadang membuat pasangan tidak sempat memberi kabar ke pasangannya. Penyebab tersebut akan menjadi beban buat pasangan dalam hal ini istri. Bagi istri pasangan jarak jauh yang tidak mempunyai aktivitas (tidak bekerja) merasa satu bulan menanti kedatangan suami yang bekerja di luar daerah sangat lama sekali.

Faktor sinyal yang turun naik ketika bertelepon dengan istri atau suami, sering membuat pembicaraan menjadi salah, misalnya suami mengatakan sinyal jelek, lalu istri menanggapinya dengan saya jelek. Terjadilah kesalahpahaman dalam komunikasi tersebut. Selain kendala tersebut terdapat kendala penting lainnya yang dialami pasangan suami istri yang melakukan jarak jauh yaitu faktor ekonomi. Pasangan membutuhkan biaya yang yang cukup tinggi untuk membayar tagihan telepon atau internet dan biaya akomodasi untuk mengunjungi pasangan, serta perhitungan waktu untuk berkunjung. Waktu yang sangat sedikit harus diperhitungkan, terkadang para dosen yang bekerja di UT tidak memiliki waktu weekend dikarenakan Sabtu-Minggu harus bekerja untuk melakukan monitoring ke daerah tempat pelaksanaan kuliah (tutorial).

Namun kendala-kendala di atas dapat diminimalisir dengan berbagai solusi, salah satunya melalui teknologi. Komunikasi jarak jauh dilakukan pasangan suami istri yang berjauhan dengan menggunakan media komunikasi. Penggunaan media komunikasi yang dilakukan oleh pasangan suami istri jarak jauh bertujuan untuk mempertahankan dan menjaga hubungan agar tetap harmonis. Salah satunya dengan menggunakan telepon dan internet, yang memudahkan dalam berkomunikasi. Intensitas dan media komunikasi yang digunakan pada pasangan suami istri jarak jauh berbedabeda. Penggunaan media dapat mewakili perasaan masing-masing pasangan melalui kecanggihannya, seperti penggunaan emoticon sebagai pengungkapan perasaan. Sedangkan komunikasi tatap muka dapat dilakukan melalui video call/skype.

Selain komunikasi, hal lain yang menjadi dasar dalam membina pernikahan jarak jauh diperlukan pemahaman yang besar mengenai konsep pernikahan tersebut oleh masingmasing pihak. Pemahaman ini diperlukan untuk menjawab tantangan-tantangan dalam menjalani pernikahan jarak jauh. Pemahaman yang seragam antarpasangan memunculkan manfaat pernikahan jarak jauh, di antaranya meningkatkan keterampilan komunikasi, adanya kepercayaan dan komitmen dari pasangan dan keluarga, adanya fleksibilitas, kebebasan yang positif, dan keinginan yang lebih untuk pengembangan diri, meningkatkan otonomi, pencapaian kepuasan bekerja yang dapat meningkatkan kepercayaan diri, fokus dalam bekerja, lebih bertanggungjawab terhadap keluarga, mampu menghadapi resiko, 
mampu mengatur waktu, anggaran, dan dapat bersosialisasi lebih luas.

Berdasarkan paparan di atas, penulis memfokuskan penelitian pada latar belakang melakukan komunikasi pasangan suami istri jarak jauh, makna keharmonisan pada pasangan suami istri yang melakukan komunikasi jarak jauh dan pengalaman komunikasi bermedia pasangan suami istri yang melakukan jarak jauh dosen dan staf administrasi UT.

Adapun yang menjadi Fokus dalam penelitian ini adalah (1) Mengetahui dan menganalisis latar belakang melakukan komunikasi pasangan suami istri jarak jauh, (2) Mengetahui dan menganalisis makna keharmonisan pada pasangan suami istri yang melakukan komunikasi jarak jauh, dan (3) Mengetahui dan menganalisis pengalaman komunikasi bermedia pasangan suami istri yang melakukan jarak jauh.

\section{METODE PENELITIAN}

Jenis penelitian dalam penelitian ini adalah studi kasus. Menurut Creswell (1998:, 37-38),

Fokus studi kasus adalah spesifikasi kasus dalam suatu kejadian, baik itu yang mencakup individu, kelompok budaya, ataupun suatu potret kehidupan. Studi kasus merupakan sebuah eksplorasi dari "suatu sistem terikat" atau "suatu kasus atau beragam kasus" yang dari waktu ke waktu melalui pengumpulan data yang mendalam serta melibatkan berbagai sumber informasi yang "kaya" dalam suatu konteks. Sistem terikat ini diikat oleh waktu dan tempat, sedangkan kasus dapat dikaji oleh suatu program, peristiwa atau suatu individu (Creswell, 1998: 61).

Studi kasus dipilih dalam penelitian ini untuk mengungkap lebih dalam potret kehidupan mengenai pasangan suami istri yang melakukan komunikasi jarak jauh dimana pasangan suami istri yang seharusnya hidup dalam satu tempat tinggal yang sama tetapi harus terpisah ruang dan waktu.. Studi kasus secara umum merupakan strategi yang lebih cocok bila pokok pertanyaan suatu penelitian berkenaan dengan "how" atau "why", bila peneliti hanya memiliki sedikit peluang untuk mengontrol peristiwa-peristiwa yang akan diselidiki, dan bilamana fokus penelitian terletak pada fenomena kontemporer (masa kini) di dalam kehidupan nyata. (Yin, 2013: 1).Berdasarkan penjelasan tersebut, penulis ingin mengkaji bagaimana komunikasi yang terjadi pada pasangan suami istri jarak jauh. Studi kasus dalam penelitian ini menggunakan studi kasus dengan tipe eksplanatoris. Penulis mengkaji lebih dalam mengenai latar belakang komunikasi pasangan yang melakukan jarak jauh, makna keharmonisan bagi pasangan suami istri yang melakukan komunikasi jarak jauh dan pengalaman komunikasi bermedia pasangan suami istri yang melakukan jarak jauh.

Teknik yang dipergunakan dalam pengumpulan data pada penelitian iniadalah wawancara mendalam, observasi, dan studi dokumentasi. Pemilihan informan kunci dilakukan dengan teknik purposive sampling. Informan dalam penelitian ini berjumlah 12 orang (6 pasangan suami istri) dan 1 orang penasihat agama dari KUA sebagai informan pendukung berasal dari Kantor Urusan Agama (KUA) Coblong Bandung, H. Ayi Zaenal Mutaqin yang menjabat sebagai kepala KUA dan penasihat perkawinan. Narasumber yang dijadikan key informant dalam penelitian ini merupakan pasangan suami istri yang melakukan komunikasi jarakjauh dilingkungan UT.

Penelitian ini hanya mengkaji dosen dan staf administrasi yang menjalani pernikahan jarak jauh di lingkungan UPBJJ Ternate, UPBJJ Padang, UPBJJ Palu, UPBJJ Bandung, dan UPBJJ Pangkal Pinang. Terdiri dari 6 pasangan suami istri yang berbeda lokasi tempat tinggal yang menjalani usia pernikahan di atas 2 tahun yang menjadi informan dalam penelitian ini. Informan untuk pasangan di UPBJJ Ternate terdiri dari 2 pasangan suami istri yang berprofesi sebagai dosen dan staf administrasi yakni informan DD dengan SS menjalani usia pernikahan selama 16 tahun dan informan YF dengan NI yang menjalani usia pernikahan selama 3 tahun 10 bulan. Sedangkan UPBJJ Padang yakni pasangan ES dengan DK sudah menjalani usia pernikahan selama 3 tahun. Informan pada UPBJJ Palu yakni MA dengan ND menjalani usia pernikahan selama 3 tahun 7 bulan. Pada UPBJJ Pangkal Pinang informan 
JK dengan IS menjalani usia pernikahan selama 12 tahun dan di UPBJJ Bandung diwakili oleh informan $\mathrm{AB}$ dengan IT yang telah menjalani usia pernikahan jarak jauh selama 8 tahun menjadi pasangan suami istri jarak jauh.

Hubungan pernikahan jarak jauh yang terjadi di UT merupakan perpisahan suami dan istri dalam jangka waktu tertentu atau perpisahan anak dengan orang tua yang disebabkan berbagai alasan, baik alasan pribadi maupun alasan yang bersifat khusus.Pasangan suami istri yang akhirnya memutuskan untuk menjalani pernikahan jarak jauh dikarenakan tuntutan karier atau pekerjaan, dari beberapa pasangan suami istri yang sebelumnya masuk UT masih berstatus lajang dan karena sudah jodoh dari Tuhan akhirnya mendapatkan pasangannya dari instansi yang sama ataupun yang sudah bekerja di beda pulau. Hal ini terjadi pada pasangan YF di mana sebelum masuk UT, YF masih berstatus lajang dan setelah menikah YF harus terpisah dengan istrinya yang memang sudah bekerja. Terpisahnya YF dikarenakan penempatan kerja ke Ternate dan YF juga mendapatkan tugas belajar di Padang pada Universitas Andalas (UNAND) Fakultas Ekonomi Jurusan Manajemen sedangkan istrinya bekerja di Pangkal Pinang sebagai PNS. Hal yang sama dirasakan oleh pasangan JK berasal dari Jakarta karena penempatan kerja di Pangkal Pinang, akhirnya JK menjalani hubungan jarak jauh dengan istri dan anakanaknya yang berada di Serang.

\section{HASIL DAN PEMBAHASAN}

Komunikasi pasangan suami istri jarak jauh pada penelitian ini dilatarbelakangi oleh jodoh, tugas belajar (memenuhi kualifikasi sebagai dosen, karir, promosi jabatan), penempatan tugas kerja (tuntutan pekerjaan) dan tuntutan ekonomi (memenuhi kebutuhan hidup). Tupoksi yang mengharuskan dosen siap ditempatkan dimana saja di seluruh Indonesia mengharuskan dosen UT terlibat pernikahan jarak jauh. Tugas belajar yang diberikan dari Universitas Terbuka juga merupakan salah satu faktor yang membuat pasangan harus hidup terpisah dengan keluarganya. Kedua hal inilah yang pada akhirnya menimbulkan adanya hubungan suami istri jarak jauh terutama yang terjadi pada dosen di Universitas Terbuka.
Maines (1993) menjelaskan bahwa pernikahan jarak jauh adalah pernikahan terpisah antara suami dengan istri yang didasari atas komitmen sebelum pernikahan karena tuntutan karir atau pekerjaan (Margiani \& Ekayati, 2013: 192).

Berdasarkan pernyataan Maines di atas, informan pada penelitian ini melakukan hubungan pernikahan jarak jauh dikarenakan tuntutan karir dan pekerjaan. Tuntutan karir penempatantugas dariJakartake Ternate, Jakarta ke Bandung, Jakarta Padang dan daerah lainnya, mengharuskan pasangan ini terpisah dengan keluarganya. Penempatan tugas belajar yang diberikan UT untuk para dosen dimaksudkan untuk peningkatan SDM dosen yang dimiliki oleh UT. Informan ND mendapatkan tugas belajar di IPB Bogor, dikarenakan latar belakang pendidikan S1 Agrobisnis dan di UPBJJ Palu bertugas di Program Studi FMIPA. Informan YF selain mendapatkan penempatan tugas ke daerah juga mendapatkan tugas belajar untuk pengembangan diri dan di UPBJJ Ternate masih sangat membutuhkan sumber daya manusia yang berkualitas untuk dapat mengembangkan kualitas UPBJJ Ternate.Penempatan tugas belajar diberikan kepada para dosen untuk pengembangan kualitas diri dosen-dosen di UT.

Penempatan tugas yang dijalani informan DD dari Jakarta ke Ternate terjadi pada awal masuk CPNS. Hal ini dikarenakan di UPBJJ UT Ternate masih kurang SDM untuk mengelola UPBJJ Ternate. Informan DK juga mendapatkan penugasan pada saat masuk CPNS. Penempatan tugas di Padang sebelumnya tidak membuat DK menjalani hubungan jarak jauh, dikarenakan status DK yangbelummenikah. DKmenjalanihubungan suami istri jarak jauh ketika menikah dengan suaminya. Baik penempatan tugas belajar maupun tugas bekerja merupakan beberapa faktor yang menyebabkan pasangan dosen di lingkungan UT melakukan hubungan jarak jauh. Seperti dikatakan oleh Rottel et. Al (Glotzer \& Federlain, 2007: 12-13) ada beberapa faktor yang menyebabkan pernikahan jarak jauh, yaitu kebutuhan keuangan (krisis keuangan), adanya mutasi kerja, adanya kesempatan yang lebih baik untuk memperbaiki kehidupan. Dari ketiga faktor tersebut, pasangan pernikahan jarak jauh cenderung melakukannya karena faktor ekonomi. 
Pertimbangan ekonomi dan mutasi pekerjaan mendapatkan jabatan yang lebih baik mengharuskan salah satu maupun kedua pihak untuk menjalani hubungan pernikahan jarak jauh. Hubungan suami istri jarak jauh yang dilakukan oleh informan dalam penelitian ini adalah untuk peningkatan kualitas diri sehingga dapat mencapai jenjang karir yang lebih baik. Tugas belajar yang dijalani oleh beberapa informan dalam menjalani hubungan jarak jauh dilakukan untuk pencapaian kualitas sebagai dosen di UT. Karena saat ini dosen diharuskan minimal pendidikannya magister. Untuk memenuhi kriteria tersebut, UT memberikan kesempatan untuk para dosennya yang belum S2 untuk melanjutkan pendidikannya. Penempatan kerja di daaerah yang dilakukan para informan adalah untuk memenuhi SDM di daerah-daerah. Informan yang ditempatkan di daerah, dipersiapkan untuk menjadi koordinataor bantuan bahan ajar (BBA) atau untuk koordinator registrasi dan ujian (REGJAN).

Adanya tuntutan mengenai jenjang karir dan perekonomian yang lebih baik membuat kondisi hubungan rumah tangga mereka sedikit banyak berubah. Perubahan yang terjadi itu seperti berkurangnya frekuensi pertemuan dan komunikasi tatap muka. Komunikasi yang mereka lakukan merupakan cara untuk memecahkan atau menyelesaikan masalah yang mereka hadapi selama berhubungan jarak jauh. Permasalahan yang dihadapi pasangan jarak jauh biasanya berupa biaya anak sekolah, uang jajan anak, kebutuhan sehari-hari, kurangnya kepercayaan dari pasangan. Masalah-masalah tersebut dapat dipecahkan dengan komunikasi secara rutin, sebagaimana yang diungkapkan oleh Duck dan Gottman dalam (Wood, 2010: 293) yaitu "kurangnya berbagi hal-hal yang kecil dalam kehidupan sehari-hari dan ekspektasi yang tidak nyata dalam menghabiskan waktu bersama sehingga dapat menjaga kehidupan mereka saling berkaitan, percakapan yang rutin dan berkelanjutan dapat membentuk fondasi hubungan".

Percakapan yang rutin dan berkelanjutan tersebut, bagi para pasangan yang melakukan hubungan jarak jauh merupakan bentuk fondasi dalam mempertahankan keharmonisan rumah tangga. Komunikasi yang mereka lakukan sebagai bentuk pembicaraan mengenai hal- hal yang kecil maupun pemecahan masalah yang dihadapi yang keseluruhannya dapat memperkuat ikatan emosional diantara mereka.

Menurut Interaksi simbolik Mead dalam Mulyana (2002: 84), pikiran mengisyaratkan adanya masyarakat; dengan kata lain, masyarakat harus lebih dulu ada sebelum adanya pikiran. Dengan demikian, pikiran adalah bagian integral dari proses sosial, bukan malah sebaliknya: proses sosial adalah produk pikiran. Jadi menurut Mead dalam West dan Turner (2008: 104) bahwa tanpa rangsangan sosial dan interaksi dengan orang lain, orang tidak akan mampu mengadakan pembicaraan dalam dirinya sendiri atau mempertahankan pemikirannya.

Menurut Mead dalam West dan Turner (2008: 105) salah satu dari aktivitas penting yang diselesaikan orang melalui pemikiran adalah pengambilan peran (role taking), atau kemampuan untuk secara simbolik menempatkan dirinya dalam diri khayalan orang lain. Proses ini juga disebut pengambilan perspektif karena kondisi ini mensyaratkan bahwa seseorang menghentikan perspektifnya sendiri terhadap sebuah pengalaman dan sebaliknya membayangkannya dari perspekif orang lain. Mead menyatakan bahwa pengambilan peran adalah sebuah tindakan simbolis yang dapat membantu menjelaskan perasaan kita mengenai diri dan juga memungkinkan kita untuk mengembangkan kapasitas untuk berempati dengan orang lain. Penempatan tugas belajar, bekerja untuk memenuhi kebutuhan ekonomi melatar belakangi pasangan suami istri jarak jauh saling bertukar peran dalam menjalani komunikasi jarak jauh.

Komunikasi pasangan jarak jauh yang dilakukan secara rutin bertujuan untuk mempertahankan keharmonisan rumah tangga. Pada pasangan, keharmonisan merupakan sesuatu yang penting saat mereka berhubungan secara jarak jauh.Pentingnya keharmonisan bagi mereka dimaknai sebagai kepercayaan dan keterbukaan antarpasangan.Keharmonisan pun disepakati oleh mereka sebagai komitmen dalam menjalani hubungan jarak jauh yang harus saling memahami dan menghargai. Djarajat (1975: 5) berpendapat bahwa keluarga yang harmonis atau keluarga bahagia adalah apabila kedua pasangan tersebut saling menghormati, saling menerima, saling 
menghargai, saling mempercayai, dan saling mencintai.

Saling mempercayai antar pasangan dalam melakukan hubungan jarak jauh ditandai dengan adanya kepercayaan berupa kepasrahan di antara mereka selama mereka melakukan komunikasi secara rutin. Kepasrahan yang dialami oleh pasangan jarak jauh merupakan bentuk kepercayaan salah satu pasangan kepada apa yang pasangan itu lakukan. Seperti kepasrahan istri yang mempasrahkan suaminya untuk melakukan kegiatan yang disukai oleh suami. Bentuk kepasrahan lainnya, yakni kepasrahan salah satu pasangan dalam mengukur keadaan diri yang sudah tidak muda lagi. Kepercayaan dalam komunikasi pasangan suami istri jarak jauh dibagi menjadi tiga bagian, yaitu pertama percayakan sepenuhnya kepada Allah SWT. Kedua, percaya pada suami, artinya lebih memberikan kepercayaan sepenuhnya segala aktivitas suami. Ketiga, kepercayaan kepada istri, artinya memberikan kepercayaan kepada istri untuk mengurus rumah tangga dan menjaga anak-anak. Kepasrahan sebagai bentuk komitmen kepercayaan antarpasangan dalam menjalani hubungan jarak jauh demi keutuhan rumah tangganya. Kunci utama pernikahan jarak jauh menurut pendapat kepala KUA Coblong adalah kepercayaan yang berujung kepasrahan dan ketaatan kepada agama. Menurut Wood (2010: 199) kepercayaan meliputi menanam rasa percaya pada seseorang dan secara emosional saling bergantung untuk menjaga kebahagian dan hubungan satu sama lain.

Walaupun adanya kepasrahan sebagai bentuk kepercayaan di antara mereka, namun rasa khawatir di antara pasangan tetap ada. Rasa khawatir ada dikarenakan pasangan lupa memberi kabar ketika ingin bepergian atau menginformasikan kegiatan yang dilakukan. Bentuk-bentuk kekhawatiran, seperti khawatir mengenai kesehatan serta khawatir keselamatan pasangan dan anak-anak.Rasa khawatir mengenai keselamatan dan kesehatan anak-anak sering ada dalam benak para suami. Para suami berpikiran bagaimana jika ada orang jahat yang akan mengganggu keluarganya dan suami tidak bisa berbuat apa-apa karena tidak ada bersama mereka. Rasa khawatir para istri lebih kepada pola makan suami dan kesehatannya.
Rasa khawatir dapat diminimalisir dengan komunikasi secara rutin dan terbuka. Keterbukaan antarpasangan jarak jauh dimaksudkan bahwa dalam berkomunikasi mereka mengungkapkan kejujuran mengenai hal-hal yang terjadi, terutama tentang masalah yang dihadapi.. Seperti yang dikatakan Glotzer dan Federlain (2007: 8-9) kondisi yang paling sulit bagi pasangan jarak jauh adalah merasakan ikatan emosi dengan pasangannya, karena sedikitnya melakukan rutinitas bersama dan kurangnya keintiman diantara pasangannya.

Menurut Mead dalam West dan Turner (2008: 105) salah satu dari aktivitas penting yang diselesaikan orang melalui pemikiran adalah pengambilan peran (role taking), atau kemampuan untuk secara simbolik menempatkan dirinya dalam diri khayalan dari orang lain. Proses ini juga disebut pengambilan perspektif karena kondisi ini mensyaratkan bahwa seseorang menghentikan perspektifnya sendiri terhadap sebuah pengalaman dan sebaliknya membayangkannya dari perspekif orang lain. Mead menyatakan bahwa pengambilan peran adalah sebuah tindakan simbolis yang dapat membantu menjelaskan perasaan kita mengenai diri dan juga memungkinkan kita untuk mengembangkan kapasitas untuk berempati dengan orang lain.

Berdasarkan pemikiran penting interaksi simbolik mengenai pentingnya makna bagi perilaku manusia, komunikasi jarak jauh dalam penelitian ini dimaknai oleh pasangan suami istri sebagai bentuk keharmonisan.Suami menempatkan dirinya sesuai dengan perspektif istrinya mengenai makna keharmonisan dan para pasangan saling berganti peran untuk memahami makna keharmonisan dalam hubungan jarak jauh. Hal ini karena makna keharmonisan yang mereka ciptakan mempermudah mereka selalu berkomunikasi walaupun jarak memisahkan mereka.Pasangan memahami keharmonisan melalui makna yang diperoleh dari pengalaman hidupnya.

Pasangan komunikasi suami istri jarak jauh memiliki perilaku komunikasi yang tidak biasa seperti pasangan yang sama-sama berada pada satu tempat. Perilaku komunikasi pasangan suami istri jarak jauh berdasarkan pengalaman mereka lebih banyak menggunakan media. Media yang digunakan merupakan alat dalam 
mendukung komunikasi pasangan tersebut. Berdasarkan hasil penelitian, media yang digunakan dalam mendukung komunikasi pasangan suami istri jarak jauh adalah telepon, skype dan SMS/ BBM. Hampir semua informan pernah menggunakan media-media tersebut. Telepon merupakan alat komunikasi yang sering gunakan karena para informan dapat dengan mudah mengakses dan langsung bisa mendengar suara pasangannya. Para pasangan biasanya menggunakan media telepon setiap hari dan bisa lebih dari 5 kaliuntuk menghubungi pasangan dan anak-anaknya. Media skype digunakan para informan untuk mengetahui keadaan masing-masing pasangannya untuk memberi kabar, melihat kegiatan anak-anak dan rasa kangen terhadap pasangannya. Media BBM atau SMS biasanya digunakan para informan untuk sekedar menanyakan kabar, mengirim foto dan menyatakan perkataan cinta.

Penggunaan media selain mempermudah mereka berkomunikasi, para pasangan suami istri jarak jauh menemukan kepuasan dengan menggunakan fasilitas teknologi yang ada pada saat ini. Kepuasaan dalam menggunakan fasilitas teknologi komunikasi saat ini selain bisa mendengar suara, para pasangan pun dapat melihat kegiatan satu sama lain dengan bertukar foto, melihat kondisi pasangan secara langsung ditempat yang berbeda dan mengirimkan pesan singkat yang disertakan emoticon (pengungkapan perasaan sedih, senang, marah, atau datar). Penggunaan media komunikasi tersebut pada pasangan dapat mengetahui keadaan atau kondisi perasaan dari pasangannya masing-masing. Penggunaan media ini dilakukan pasangan suami istri jarak jauh untuk mengurangi rasa kangen kepada pasangannya.

Penggunaan media tersebut tidak terlepas dari perilaku verbal dan nonverbal.Perilaku verbal dari pasangan jarak jauh dapat diketahui ketika pasangan berkomunikasi menggunakan skype. Melalui skype mereka dapat mengetahui secara langsung ekspresi pasangannya saat menelpon, dengan wajah berseri-seri dengan saling bercerita mengenai keadaan masingmasing dan kegiatan apa saja yang dilakukan. Perilaku pasangan jarak jauh nonverbal dapat diketahui melalui intonasi suara dan pesan singkat. Saat menelpon, pasangan dapat mengetahui apakah pasangannya antusias saat mendengarkan pembicaraan di telepon. Nada bicara “...yah udah ya.." berarti pasangan dalam keadaan sibuk dan tidak sedang mood untuk melanjutkan pembicaraan. Penggunaan pesan nonverbal yang dilakukan pasangan suami istri jarak jauh adalah dengan menggunakan pesan singkat yang disertai dengan emoticon untuk mengekspresikan keadaannya. Seperti ketika suami mengungkapkan perasaan rindu, suami akan mengirimkan simbol "love" melalui media seperti BBM atau chatting maka istri akan mengerti bahwa suaminya sedang rindu. Simbol "love" sebagai tanda rindu telah menjadi simbol yang umum pengguna media BBM dan chatting. Pemaknaan simbol tersebut akan diungkapkan secara langsung ketika pasangan suami istri bertemu. Penulisan kata love yang diberikan suami kepada istrinya dalam penelitian ini menggambarkan walau berbeda jarak mereka tetap saling sayang.

Perilaku komunikasi pasangan suami istri jarak jauh tidak terlepas dari rutinitas. Rutinitas komunikasi pasangan suami istrijarak jauh menggambarkan bagaimana kegiatan berkomunikasi yang dilakukan oleh pasangan ini. Dikarenakan pasangan suami istri jarak jauh hanya dapat bertemu pada waktu-waktu tertentu saja.Umumnya pasangan memulai komunikasi di antara mereka pada pagi hari, siang, dan malam. Di mana komunikasi pagi hari dilakukan sebelum berangkat kerja atau pada saat baru bangun tidur. Pembicaraan pagi hari biasanya untuk membangunkan pasangan atau anak dan menanyakan sudah sarapan dan jangan sampai telat berangkat ke kantor atau berangkat sekolah. Komunikasi siang hari biasannya dilakukan pada saat istirahat untuk menanyakan sudah istirahat(sholat danmakan). Sedangkan komunikasi malam hari dilakukan pada saat ingin tidur.Komunikasi malam hari lebih bersifat santai, karena waktunya yang panjang dan segala aktivitas telah selesai. Biasanya pasangan membicarakan kegiatan tadi siang (pekerjaan, rumah, anak-anak) dan membicarakan hal-hal yang ringan.

Komunikasi pasangan jarak jauh dalam menjalani hubungan suami istri jarak jauh tidak terlepas dari kendala komunikasi. Kendala komunikasi yang ada dikarenakan jarak yang berbeda dan terkadang sulit dijangkau untuk pasangan melakukan komunikasi. Kendala komunikasi yang dihadapi pasangan jarak 
jauh, yaitu sinyal atau jaringan, biaya, dan waktu. Jaringan telepon atau internet yang tidak stabil terkadang menimbulkan missed komunikasi pada pasangan. Pasangan merasa kecewa dan marah karena sedang menelepon tiba-tiba sambungan telepon mati. Akhirnya prasangka negatif dari pasangan timbul dan menyebabkan missed komunikasi. Sinyal yang tidak stabil juga menyebabkan pengucapan kalimat "sayang sinyalnya jelek" dimaknai berbeda oleh pasangannya dan disangka pasangannya itu mengatakan bahwa "...apa yang? Saya jelek...'.Selain sinyal yang tidak stabil, biaya pemakaian telepon atau internet juga menjadi kendala. Biaya telepon atau internet yang cukup tinggi harus dipersiapkan oleh pasangan suami istri jarak jauh setiap bulannya dan dimasukkan dalam perhitungan anggaran pengeluaran bulanan. Kendala komunikasi pasangan suami istri jarak jauh yang berikutnya adalah kendala waktu. Pasangan jarak jauh harus menyesuaikan waktu yang tepat untuk dapat berkomunikasi dengan pasangannya. Pasangan harus mengetahui kapan waktu yang senggang untuk mereka berkomunikasi. Keinginan bertemu dengan pasangan untuk dapat mencurahkan perasaannya secara langsung juga merupakan kendala waktu yang dihadapai pasangan suami istri jarak jauh.

Perilaku verbal dan nonverbal pada pasangan jarak jauh saat berkomunikasi menggunakan media merupakan bahasa yang dalam konsep Mead termasuk pada konsep mind. Bahasa menurut konsep mind adalah sebuah sistem verbal dan nonverbal yang diatur dalam pola-pola untuk mengekspresikan pemikiran dan perasaan yang dimiliki bersama (West dan Turner, 2008: 105). Adapun bahasa yang digunakan oleh pasangan suami istri jarak jauh menggunakan Bahasa Indonesia yang informal. Bahasa tersebut sebagai bentuk ekspresi dari pemikiran dan perasaan tentang masingmasing pasangan, mulai dari mengekspresikan perasaan sayang, marah, pemecahan masalah, dan pengungkapan rasa kangen.

Selain perilaku verbal dan non verbal, perubahan perilaku juga terjadi pada pasangan suami istri jarak jauh. Perubahan perilaku pasangan di sini lebih bersifat positif, yakni seorang istri yang sebelumnya tidak pandai memasak jadi lebih pandai dan lebih variatif dalam memasak. Para suami yang sebelumnya tidak bisa mengurus diri sendiri karena jauh dengan istri, jadi sudah bisa dan mandiri untuk mengurus diri.

Komunikasi dilakukan melalui media seperti, SMS/BBM, telepon, ataupun skype. Komunikasibermediadigunakanolehpasangan suami istri jarak jauh untuk mengetahui keadaan masing-masing pasangan, mengenai rutinitas keseharian yang dilakukan, kondisi anak, atau sekedar menyampaikan rasa rindu ingin bertemu. Komunikasi yang dilakukan pasangan suami istri jarak jauh ini dijalankan dengan memaknai bahwa dalam menjaga hubungan suami istri jarak jauh harus dilandasi dengan keterbukaan dan kepercayaan.Namun kadangkala dalam membangun keterbukaan dan kepercayaan itu, pasangan suami istri kerap kali menemui hambatan/ kendala dalam berkomunikasi jarak jauh. Kendala yang di hadapi dalam komunikasi jarak jauh oleh pasangan suami istri, diantaranya mahalnya biaya yang dikeluarkan untuk komunikasi jarak jauh ini, yaitu biaya telepon yang mahal dan pembayaran internet. Selain biaya yang tinggi, kendala yang dihadapi menyangkut sinyal dan waktu. Sinyal provider yang digunakan terkadang sering turun naik sehingga dapat mengakibatkan miss komunikasi. Sementara, waktu menjadi kendala tersendiri bagi pasangan suami istri jarak jauh yang ingin bertemu/ jadwal bertemu tapi tidak bisa bertemu karena ada kesibukan tambahan. Jadwal bertemu idealnya sebulan sekali tetapi karena kesibukan tersebut mengakibatkan jadwal bertemu menjadi 3 sampai 4 bulan sekali.Intensitas pertemuan yang sangat jarang dilakukan mengakibatkan pentingnya untuk saling berkomunikasi menggunakan media.

Pengalaman berkomunikasi melalui media ini merupakan pengganti komunikasi secara tatap muka dan langsung yang dilakukan pasangan jarak jauh. Hal ini pun menunjukkan bahwa interaksi yang berlangsung diantara pasangan lebih banyak menggunakan media daripada secara tatap muka, sehingga bentuk sentuhan, pertemuan secara fisik jarang terjadi. Hal ini berimbas pada perilaku pasangan jarak jauh dimana ketergantungan terhadap pasangan lebih sedikit dibandingkan dengan pasangan yang tidak menjalani hubungan jarak jauh.

Hasil dan pembahasan di atas dapat 
digambarkan dalam model komunikasi pasangan suami istri jarak jauh di lingkungan UPBJJ di bawah ini:

Berangkat dari model di atas, komunikasi

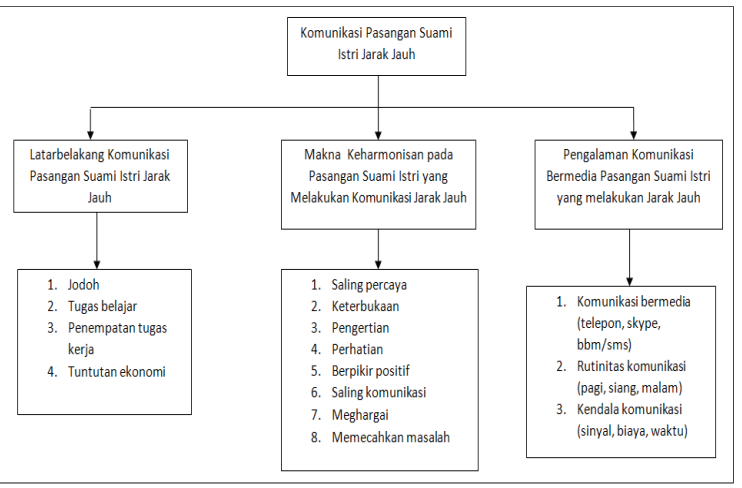

Bagan 1. Komunikasi Pasangan Suami Istri

Jarak Jauh di Lingkungan Universitas Terbuka Sumber: Penulis, 2014

pasangan suami istri jarak jauh dilihat dari tiga aspek, yaitu: latar belakang, makna keharmonisan dan pengalaman. Latar belakang komunikasi pasangan suami istri jarak jauh dikarenakan penempatan kerja, tugas belajar dan mempertahankan keharmonisan.Makna keharmonisan dari pasangan suami istri jarak jauh mengenai keterbukaan dan kepercayaan dalam rumah tangga. Pengalaman komunikasi pasangan suami istri jarak jauh dapat dilihat dari komunikasi bermedia (verbal, non verbal), rutinitas komunikasi pasangan dan kendala komunikasi pasangan suami istri jarak jauh.

\section{SIMPULAN}

Latar belakang komunikasi pasangan suami istri jarak jauh yang terdapat di lingkungan Universitas Terbuka karena adanya tupoksi penempatan kerja, tugas belajar, dan mempertahankan keharmonisan. Penempatan kerja dan tugas belajar membuat pasangan menjalani hubungan jarak jauh. Adanya tuntutan mengenai jenjang karir dan perekonomian yang lebih baik membuat kondisi hubungan rumah tangga mereka sedikit banyak berubah. Perubahan yang terjadi itu seperti berkurangnya frekuensi pertemuan dan komunikasi tatap muka. Berkurangnya kebiasaan tersebut membuat pasangan UPBJJ UT yang menjalani hubungan jarak jauh melakukan komunikasi secara rutin untuk mempertahankan keharmonisan rumah tangganya.

Makna keharmonisan bagi pasangan komu- nikasi jarak jauh terdiri dari dua bagian, yaitu kepercayaan dan keterbukaan. Kepercayaan sangat diperlukan dalam sebuah hubungan, terlebih lagi untuk hubungan jarak jauh. Kepercayaan diterapkan oleh pasangan suami istri untuk menjaga keharmonisan rumah tangganya. Selain kepercayaan, keterbukaan juga sangat penting dalam hubungan jarak jauh. Keterbukaan antarpasangan dalam berkomunikasi artinya tidak ada hal yang ditutupi oleh pasangan.

Pengalaman komunikasi pasangan suami istri jarak jauh menggunakan media sebagai sarana untuk berkomunikasi. Pengalaman komunikasi dibagi menjadi dua bagian, yaitu komunikasi bermedia (verbal, nonverbal) dan perubahan perilaku. Kedua, rutinitas komunikasi (pagi, siang, malam), dan ketiga kendala komunikasi (sinyal, biaya, dan waktu). Komunikasi pasangan suami istri yang melakukan komunikasi jarak jauh didominasi oleh komunikasi bermediaHal ini berimbas pada perilaku pasangan jarak jauh di mana ketergantungan terhadap pasangan.

Berdasarkan penelitian yang telah dilakukan adapun saran yang dapat membantu perbaikan cara berkomunikasi pasangan suami istri jarak agar mempertahankan keharmonisan rumah tangganya adalah meningkatkan frekuensi komunikasi dalam pasangan suami istri jarak jauh. Pasangan suami istri jarak jauh diharapkan bisa mencari teman sepergaulan jadi bisa saling bertukar cerita antara sesama keluarga jarak jauh. Selain itu, waktu berkomunikasi pasangan suami istri jarak jauh harus disesuaikan dengan waktu yang tepat antara pasangan agar terhindar dari kesalahpahaman karena misscommunication.

\section{DAFTAR PUSTAKA}

Creswell, J. W. (1998). Qualitative inquiry and research design: choosing among five traditions. The United State of America: Sage Publication, Inc.

Dradjat, Z. (1975). Ketenangan dan kebahagiaan dalam keluarga. Jakarta: Bulan Bintang.

Glotzer, R. \& Federlain, A. C. (2007). Milles that Blind: Commuter marriage anf Familly Strenght. Michigan Family 
Review, Volume 12, 7-31.

Margiani, K \& Ekayati,I. N. (2013). Stres, dukungan keluarga dan agresivitas pada istri yang menjalani pernikahan jarak jauh. Dalam Persona Jurnal Psikologi Indonesia, Vol.2, No.3, September 2013, Hal. 191-198.

Mulyana, D. (2002). Metodologi penelitian kualitatif: paradigma baru ilmu komunikasi dan ilmu sosial lainnya. Bandung: Remaja Rosdakarya.

Universitas Terbuka.(2014).Data universitas terbuka. Jakarta: Universitas Terbuka

West, R. \& Turner, L. H. (2008). Pengantar teori komunikasi analisis dan aplikasi. Jakarta: Salemba Humanika

Wood, J. T. (2010). Interpersonal communication: everyday encounters. Boston: Wardsworth.

Yin, R. K. (2013). Studi kasus: desain dan metode. Jakarta: RajaGrafindo Persada. 